Jumpal par

http://jurnal.bhmm.ac.id/index.php/jpkm/index

Corresponding Author.

email address : nerserwin.08@gmail.com

Erwin Kurniasih

Received : 29 Juli 2020

Revised : 20 Agustus 2020

Accepted : 14 September 2020

\title{
Sarapan Pagi dan Konsentrasi Belajar Anak Sekolah Dasar Negeri 02 Balerejo Kabupaten Madiun Erwin Kurniasih $^{1}$, Endri Ekayamti ${ }^{2}$
}

\author{
${ }^{1,2^{*}}$ Akademi Keperawatan Pemerintah Kabupaten Ngawi \\ Email: nerserwin.08@gmail.com
}

\begin{abstract}
ABSTRAK
Sarapan pagi penting dan berdampak terhadap kondisi kesehatan jasmani terutama pada anak usia sekolah. Siswa Kelas 4 dan 5 SD Negeri 02 Balerejo memiliki kebiasaan waktu pelajaran banyak yang gelisah karena rasa lapar Penelitian ini bertujuan untuk mengetahui hubungan sarapan pagi dengan konsentrasi belajar siswa kelas 4 dan 5 di SD Negeri 02 Balerejo Kabupaten Madiun tahun 2019. Desain penelitian ini adalah cross sectional. Populasi pada penelitian ini adalah siswa kelas 4 dan 5 SD Negeri 02 Balerejo sebanyak 40 anak. Pengambilan sampel pada penelitian ini menggunakan teknik simple random sampling sehingga didapatkan sampel sebanyak 36 anak. Pengumpulan data pada penelitian ini menggunakan wawancara dan lembar observasi. Analisis data hasil penelitian meliputi analisis univariat dan analisis bivariat menggunakan uji chi square. Hasil penelitian menunjukan bahwa sebagian besar $52,8 \%$ responden tidak sarapan pagi dan sebagian besar $66,7 \%$ responden dengan tingkat konsentrasi belajar kurang baik. Berdasarkan hasil analisis statistik di dapatkan nilai $\mathrm{p}=$ 0,024 dan $\mathrm{PR}=3,75$ artinya ada hubungan yang signifikan antara sarapan pagi dengan tingkat konsentrasi belajar siswa. Untuk itu diharapkan kepada semua pihak, baik pihak sekolah maupun orang tua untuk dapat melakukan upaya dalam membiasakan sarapan pagi bagi anak sebelum berangkat ke sekolah.
\end{abstract}

Kata Kunci : Sarapan Pagi, Konsentrasi Belajar

\begin{abstract}
Breakfast is important and has an impact on physical health conditions, especially for school age children. Students in Grade 4 and 5 of SD Negeri 02 Balerejo had a habit of restless class time because of hunger. This study aimed to determine the relationship between breakfast and the learning concentration of grade 4 and 5 students at SD Negeri 02 Balerejo, Madiun Regency in 2019. This study used Cross sectional research design. The population in this study were 40 students of grade 4 and 5 SD Negeri 02 Balerejo.
\end{abstract}

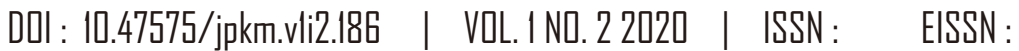


Sampling in this study used simple random sampling technique in order to obtain a sample of 36 children. Collecting data in this study used interviews and observation sheets. Analysis of research data included univariate analysis and bivariate analysis using the chi square test. The results showed that most of the $52.8 \%$ of respondents did not eat breakfast and most of the $66.7 \%$ of respondents with poor concentration levels of learning. Based on the results of statistical analysis, the value of $p=0.024$ and $\mathrm{PR}=3.75$ means that there was a significant relationship between breakfast and the concentration level of student learning. For this reason, it is hoped that all parties, both schools and parents, can make efforts to get the kids breakfast used to before leaving for school.

Keywords : Breakfast, learning concentration

\section{PENDAHULUAN}

Konsentrasi belajar merupakan suatu pemusatan pikiran atau perhatian terhadap pelajaran. Konsentrasi memiliki peranan penting bagi seorang anak dalam mengingat, merekam dan mengembangkan materi pelajaran di sekolah. Untuk melakukan kemampuan peranan tersebut anak sudah dapat berfikir secara logis serta membuat keputusan tentang apa yang akan dihubungkan secara logis, masa-masa tersebut terjadi pada usia umur 11-13 tahun (Suwardhani, 2013).Di Indonesia 18,05\% anak tidak sarapan pagi. Berdasarkan data Rikesdas, 2010 bahwa mutu sarapan penduduk Indonesia masih rendah karena masih banyak anak yang tidak terbiasa sarapan sehat. Penduduk yang mengkonsumsi energi di bawah kebutuhan minimal lebih rendah dari 70\%. Angka Kecukupan Gizi (AKG) bagi orang Indonesia tahun (2004) adalah sebanyak 40,6\%. Proporsi defisit energi terbanyak pada anak usia sekolah $(41,2 \%)$, remaja $(54,5 \%)$ dan ibu hamil $(44,2 \%)$. Pada anak usia sekolah konsumsi energi $<70 \%$ yaitu $50,6 \%$ usia $7-12$ tahun dan 39,3\% usia $13-15$ tahun sedangkan konsumsi protein 31,6\% usia 7-12 tahun dan 23,5\% usia 13-15 tahun. Ini sejalan dengan penelitian yang dilakukan oleh Anam, 2012 bahwa anak yang tidak biasa sarapan pagi mudah lelah dan tidak kuat melakukan aktifitas, tidak mampu berpikir dan tidak berpartisipasi penuh dalam belajar.

Pada tahun 2013 terjadi peningkatan jumlah kasus gizi buruk di jawa timur, yaitu dari tahun 2012 yaitu sebesar 8.410 kasus meningkat menjadi 11.056 kasus. Sedangkan dari tahun 2013 hingga tahun 2016 mengalami penurunan yakni sebesar 5.663 kasus. Ada kemungkinan penurunan jumlah kasus tersebut antara lain gencarnya petugas gizi di masyarakat untuk menemukan secara dini kasus gizi buruk di lapangan (DINKES JATIM, 2018).

Faktor yang mempengaruhi konsentrasi belajar anak terdiri atas dua faktor yakni faktor dalam seperti psikologi meliputi bakat, minat, motivasi, ingatan kebiasaan dan status gizi meliputi pola konsumsi makan keluarga, persediaan pangan keluarga, sarapan pagi, pendapatan keluarga dan zat gizi dalam keluarga, faktor luar seperti non sosial yang meliputi lingkungan, latihan, metode belajar, sarana dan prasarana serta bahasa, budaya dan sosial yang meliputi guru dan orang tua, (Anam, 2012).

Menurut Hardinsyah dalam Imam Firmansyah (2015) mengatakan bahwa sarapan yang sehat harus mencakup 4 hal. Pertama adalah jenisnya, terutama untuk makanan dan minuman. Kedua, tercukupinya kebutuhan gizi 15-30\% dari kebutuhan harian. Ketiga makanan harus aman dan terbebas dari berbagai pencemaran dan yang terakhir adalah waktu. Sarapan dibutuhkan untuk mengisi lambung yang telah kosong selama 8-10 jam dan bermanfaat dalam meningkatkan kemampuan konsentrasi belajar dan kemampuan fisik (Martianti, 2006).

Sarapan bertujuan untuk memenuhi 2 kebutuhan zat gizi di pagi hari, sebagai bagian dari pemenuhan gizi seimbang dan bermanfaat dalam mencegah hipoglikemia, menstabilkan kadar glukosa darah, dan mencegah dehidrasi setelah berpuasa sepanjang malam.

\section{METODE PENELITIAN}

Jenis penelitian yang digunakan adalah penelitian kuantitatif menggunakan Desain Korelasional dengan pendekatan cross-sectional. Sampel dalam penelitian ini diambil dengan teknik simple random sampling. Pengambilan sampel dilakukan dengan cara menulis nama pada kertas, dibentuk lot, ditaruh di dalam wadah kemudian di kocok dan dijatuhkan. Populasi dalam penelitian ini adalah seluruh siswa kelas IV dan V sejumlah 40 orang di Sekolah Dasar Negeri 2 Balerejo Kabupaten Madiun tahun pelajaran 2018/2019. 
Sampel pada penelitian ini adalah anak kelas 4 dan 5 di Sekolah Dasar Negeri 2 Balerejo Kabupaten Madiun yang sesuai dengan kriteris inklusi dan eksklusi yang diharapkan. Besar sampel pada penelitian ini menggunakan rumus besar slovin, dengan kriteria inklusi dan eksklusi.

Teknik Sampling pada penelitian ini menggunakan Simple random sampling. Uji statistik yang digunakan yaitu uji Chi Square dengan tingkat $\alpha$ yang di ambil 0,05.

\section{HASIL DAN PEMBAHASAN}

1. Karakteristik Responden Berdasarkan Jenis Kelamin

Tabel 1. Karakteristik Responden Berdasarkan Jenis Kelamin

\begin{tabular}{|c|c|c|c|}
\hline No & $\begin{array}{c}\text { Jenis } \\
\text { Kelamin }\end{array}$ & Frekuensi & Presentase \\
\hline 1 & Perempuan & 16 & 56 \\
\hline 2 & Laki-Laki & 20 & 44 \\
\hline & Total & 36 & 100 \\
\hline
\end{tabular}

Sumber : data primer, di SDN 02 Belerejo Kabupaten Madiun

Berdasarkan tabel diatas karakteristik jenis kelamin peseta didik sebagian besar adalah laki-laki dengan jumlah sebanyak $20 \operatorname{anak}(56 \%)$.

2. Karakterisitik Responden Berdasarkan Usia

Tabel 2. Karakterisitik Responden Berdasarkan Usia

\begin{tabular}{|c|c|c|c|}
\hline No & Usia & Frekuensi & Presentase \\
\hline 1 & $9-10$ & 19 & 52 \\
\hline 2 & $10-11$ & 17 & 48 \\
\hline \multicolumn{2}{|c|}{ Total } & 36 & 100 \\
\hline
\end{tabular}

Sumber : data primer, di SDN 02 Belerejo Kabupaten Madiun

Berdasarkan tabel diatas dapat diketahui bahwa sebagian besar usia responden adalah 9-10 tahun yang berjumlah 19 anak (52\%).

3. Karakteristik Responden Berdasarkan Pekerjaan Orang Tua

Tabel 3. Karakterisitik Responden Berdasarkan Pekerjaan Orang Tua

\begin{tabular}{|c|c|c|c|}
\hline No & Pekerjaan & Frekuensi & Presentase \\
\hline 1 & Petani & 19 & 52 \\
\hline 2 & Wiraswasta & 10 & 28 \\
\hline 3 & PNS & 3 & 8 \\
\hline 4 & Lain-lain & 4 & 12 \\
\hline \multicolumn{2}{|c|}{ Total } & 36 & 100 \\
\hline
\end{tabular}

Sumber : data primer, di SDN 02 Belerejo Kabupaten Madiun 
Berdasarkan tabel di atas dapat disimpulkan bahwa sebagian besar pekerjaan orang tua yaitu petani sebanyak 19 orang (52\%). Sedangkan sebagian kecil adalah PNS sebanyak 3 orang (8\%).

4. Karakteristik Responden Berdasarkan Intensitas Sarapan Pagi.

Tabel 4. Karakteristik Responden Berdasarkan Intensitas Sarapan Pagi

\begin{tabular}{|c|c|c|c|}
\hline No & $\begin{array}{c}\text { Intensitas } \\
\text { Sarapan }\end{array}$ & Frekuensi & Presentase \\
\hline 1 & $\begin{array}{c}\text { Tidak } \\
\text { Pernah }\end{array}$ & 6 & 16 \\
\hline 2 & Kadang & 14 & 39 \\
\hline 3 & Sering & 11 & 31 \\
\hline 4 & Selalu & 5 & 14 \\
\hline \multicolumn{2}{|c|}{ Total } & 36 & 100 \\
\hline
\end{tabular}

Sumber : data primer, di SDN 02 Belerejo Kabupaten Madiun

Berdasarkan tabel di atas dapat disimpulkan bahwa sebagian besar peserta didik jarang sarapan pagi sebanyak 14 anak (39\%). Sedangakan sebagian kecil peserta didik selalu sarapan pagi sebanyak 5 anak $(14 \%)$.

5. Karakteristik Responden Berdasarkan Jenis Makanan.

Tabel 5. Karakteristik Responden Berdasarkan Jenis Makanan

\begin{tabular}{|c|c|c|c|}
\hline No & Menu Sarapan & Frekuensi & Presentase \\
\hline 1 & Nasi,lauk dan sayur & 6 & 16 \\
\hline 2 & Nasi dan lauk & 15 & 42 \\
\hline 3 & Nasi,lauk,sayur dan susu & 7 & 20 \\
\hline 4 & Nasi,lauk dan susu & 2 & 5 \\
\hline 5 & Roti dan susu & 4 & 12 \\
\hline 6 & Susu & 2 & 5 \\
\hline & Total & 36 & 100 \\
\hline
\end{tabular}

Sumber : data primer, di SDN 02 Belerejo Kabupaten Madiun

Berdasarkan tabel 5 di atas dapat disimpulkan bahwa sebagian besar peserta didik jenis makanan yang dikonsumsi adalah nasi dan lauk sebanyak 15 anak (42\%).

Berdasarakan hasil penelitian distribusi frekuensi responden berdasarkan data khusus. Madiun

1. Distribusi Frekuensi Sarapan Pagi Pada Siswa Sekolah Dasar Negeri 02 Balerejo Kabupaten 
Tabel 6. Distribusi Frekuensi Sarapan Pagi Pada Siswa Sekolah Dasar Negeri 02 Balerejo Kabupaten Madiun

\begin{tabular}{|c|c|c|c|}
\hline No & $\begin{array}{c}\text { Sarapan } \\
\text { pagi }\end{array}$ & Frekuensi & Presentase \\
\hline 1 & Ya & 16 & 47,2 \\
\hline 2 & Tidak & 20 & 52,8 \\
\hline \multicolumn{2}{|c|}{ Total } & $\mathbf{3 6}$ & $\mathbf{1 0 0}$ \\
\hline
\end{tabular}

Sumber : data primer, wawancara responden di SDN 2 Balerejo Madiun

Berdasarkan tabel di atas menunjukan bahwa sebagian besar siswa yang tidak melakukan sarapan sebanyak 20 orang $(52,8 \%)$. Madiun

2. Distribusi Frekuensi Konsentrasi Belajar Pada Siswa di Sekolah Dasar Negeri 02 Balerejo

Tabel 7. Distribusi Frekuensi Konsentrasi Belajar Pada Siswa di Sekolah Dasar Negeri 02 Balerejo Madiun

\begin{tabular}{|c|l|c|c|}
\hline No & Konsentrasi Belajar & Frekuensi (f) & Presentase (\%) \\
\hline 1 & Baik & 12 & 33,3 \\
\hline 2 & Kurang & 24 & 66,7 \\
\hline \multicolumn{2}{|c|}{ Total } & $\mathbf{3 6}$ & $\mathbf{1 0 0}$ \\
\hline
\end{tabular}

Sumber : data primer, observasi responden di SDN 2 Balerejo Madiun

Berdasarkan tabel di atas menunjukan bahwa sebagian besar konsentrasi belajar siswa adalah rendah yaitu sebanyak 24 orang $(66,7 \%)$.

3. Hubungan Sarapan Pagi Dan Konsentrasi Belajar Pada Siswa Sekolah Dasar Negeri 02 Balerejo Madiun

Tabel 8. Hubungan Sarapan Pagi Dan Konsentrasi Belajar Pada Siswa Sekolah Dasar Negeri 02 Balerejo Madiun

\begin{tabular}{|c|c|c|c|c|c|c|}
\hline \multirow{3}{*}{ Sarapan Pagi } & \multicolumn{4}{|c|}{ Konsentrasi belajar } & \multirow{3}{*}{ Jumlah } & \multirow[t]{3}{*}{$\%$} \\
\hline & \multicolumn{2}{|c|}{ Baik } & \multicolumn{2}{|c|}{ Kurang } & & \\
\hline & Jumlah & $\%$ & Jumlah & $\%$ & & \\
\hline Ya & 9 & 56,2 & 7 & 43,8 & 16 & 100 \\
\hline Tidak & 3 & 15 & 17 & 85 & 20 & 100 \\
\hline Jumlah & 12 & & 24 & & 36 & 100 \\
\hline PR & \multicolumn{6}{|c|}{3,75} \\
\hline P-value & \multicolumn{6}{|c|}{0,024} \\
\hline
\end{tabular}

Sumber : data primer, wawancara dan observasi responden di SDN 2 Balerejo Madiun tahun 2019 
Pengolahan data untuk mengetahui hubungan sarapan pagi dengan konsentrasi belajar adalah menggunakan Uji Chi Square. Uji ini digunakan untuk membuktikan hipotesis yaitu ada tidaknya hubungan sarapan pagi dengan konsentrasi belajar anak di SDN 02 Balerejo Kabupaten Madiun. Berdasarkan hasil uji Chi Square dengan nilai continuity correction didapatkan nilai p $0,024<=0,05$ maka dapat dikatakan ada hubungan antara sarapan pagi dengan konsentrasi belajar anak di SDN 02 Balerejo Madiun.

\section{PEMBAHASAN}

Berdasarkan hasil penelitian diketahui bahwa siswa-siswi SDN 02 Balerejo Kabupaten Madiun kelas 4 dan 5 mempunyai kebiasaan tidak sarapan pagi sebelum berangkat ke sekolah yakni 52,8\% dikarenakan orang tua siswa yang mayoritas bekerja sebagai petani yang harus berangkat ke sawah pagi hari. Di SDN 02 balerejo mayoritas siswa kadang-kadang makan pagi(39\%), dengan karakteristik nasi dan lauk(42\%) ada sebagian siswa yang tidak sarapan tetapi membawa bekal. Ada pula anak yang sekedar sarapan hanya dengan segelas air putih, teh, susu, atau kue-kue (snack) maka bias di katakana kebutuhan gizinya kurang.

Sarapan pagi sangat penting dan bermanfaat bagi anak usia sekolah. Dimana jarak antara waktu makan berkisar 8 jam, sehingga pada pagi hari perut kosong. Hardinsyah \& Aries (2012) menegaskan bahwa individu yang seringkali tidak sarapan cenderung menunjukkan fisik yang lemas, kurang fit, terkadang terlihat mengantuk bahkan dapat juga mengalami pusing. Sarapan penting dilakukan setiap hari untuk mengembalikan kadar gula dalam darah. Dalam penelitian yang dilakukan oleh (Frankling dalam Suwardhani, 2013) tentang asupan makanan bahwa kandungan glukosa berperan dalam meningkatkan kinerja otak. Ketidak cukupan glukosa di otak member efek terhadap daya piker dan daya ingat. Kadar glukosa yang terus-menerus mengalami penurunan karena tidak diimbangi sarapan akan berdampak negatif bagi tubuh, yakni gizi setelah bangun pagi.

Menurut asumsi peneliti, sebagian dari SD Negeri 2 Balerejo Kabupaten Madiun tidak memiliki kebiasaan sarapan pagi sebelum berangkat ke sekolah, dimana responden menyatakan bahwa tidak selalu sarapan pagi atau tidak terbiasa sarapan pagi. Kondisi ini terjadi akibat pola asuh orang tua yang kurang tepat serta kurangnya perhatian orang tua tentang sarapan pagi bagi anak. Sebagian besar pekerjaan orang tua peserta didik sebagai petani (52\%) yang biasa berangkat ke sawah terlalu pagi sehingga kesempatan mempersiapkan sarapan pagi peserta didik lebih sedikit. Hal ini tentu menjadi perhatian bagi semua pihak untuk meningkatkan pengetahuan orang tua tentang pentingnya sarapan pagi agar orang tua dapat berperilaku sehat dengan menyediakan sarapan pagi serta membiasakan anak-anak mereka untuk sarapan pagi setiap hari.

Berdasarakan hasil penelitian menunjukkan bahwa dari 36 responden terdapat 24 siswa $(66,7 \%)$ kategori konsentrasi kurang. Sebagian besar anak saat proses belajar mengajar berlangsung siswa banyak yang bercanda dengan temannya, bengong dan gelisah tidak fokus ke materi pelajaran yang di terangkan oleh guru.

Konsentrasi adalah memfokuskan pikiran kepada satu hal yang dihadapan kita. Konsentrasi akan menjadi tidak berarti apa bila ada gangguan. Faktor-faktor yang mempengaruhi konsentrasi belajar adalah faktor sosial yang meliputi guru, orang tua dan teman. Faktor non sosial yang meliputi lingkungan, metode belajar, sarana dan prasarana. Faktor psikologi meliputi bakat, minat, ingatan dan motivasi. Faktor terakhir yaitu kebiasaan sarapan pagi, pola konsumsi makanan keluarga, persediaan pangan keluarga dan pendapatan keluarga Tamsuri, (2010).

Menurut asumsi peneliti masih banyak ditemukan bahwa siswa SD Negeri 2 Balerejo Kabupaten Madiun dengan tingkat konsentrasi belajar yang kurang dimana sikap belajar peserta didik di kelas menunjukan kurangnya konsentrasi terhadap kegiatan belajar mengajar seperti siswa berbicara sendiri dengan teman sebangkunya di luar topik pembelajaran, bengong dan siswa tidak memperhatikan guru yang sedang mengajar. Rendahnya konsentrasi belajar pada siswa SD Negeri 2 Balerejo Kabupaten Madiun dipengaruhi oleh beberapa faktor, diantara lain faktor materi pelajaran, faktor lingkungan, tingkat intelejensi dan faktor kesehatan jasmani yang meliputi kurangnya gizi dan asupan tenaga dikarenakan sebagian besar $(52,8 \%)$ peserta didik tidak terbiasa sarapan pagi dikarenakan pekerjaan orang tua siswa yang mayoritas bekerja sebagai petani yang harus berangkat kerja pagi dan tidak sempat menyiapkan sarapan untuk anaknya. 
Berdasarkan hasil uji Chi Square dengan nilai continuity correction didapatkan nilai p 0,024< $=0,05$ maka dapat dikatakan ada hubungan antara sarapan pagi dengan konsentrasi belajar anak di SDN 02 Balerjo Madiun. Sesuai hasil tabel diatas, hasil nilai OR sebesar 7,286 maka dapat disimpulkan bahwa jarang sarapan pagi memiliki resiko lebih besar untuk mengalami gangguan konsentrasi belajar pada anak.

\section{KESIMPULAN}

1. Siswa Sekolah Dasar Negeri 2 Balerejo yang dapat disimpulkan bahwa yang tidak sarapan pagi $(52,7 \%)$.

2. Siswa Sekolah Dasar Negeri 2 Balerejo yang dapat disimpulkan bahwa konsentrasi belajar kurang $(66,7 \%)$.

3. Ada Hubungan sarapan pagi dengan konsentrasi belajar anak Sekolah Dasar Negeri 2 Balerejo ( $\mathrm{p}$ value $=0,024)$

\section{SARAN}

\section{Bagi Institusi Pendidikan STIKES BHM Madiun}

Diharapkan kepada pihak institusi pendidikan, khususnya pendidikan kesehatan untuk selalu meningkatkan bimbingan dan penekanan materi tentang ilmu keperawatan anak yaitu tentang sarapan pagi terhadap pemenuhan kebutuhan gizi, nutrisi dan tingkat konsentrasi belajar anak.

\section{Bagi Guru SDN 2 Balerejo Kabupaten Madiun}

Hasil penelitian ini dapat dijadikan sebagai sumber referensi dan daftar pustaka berkaitan dengan hubungan sarapan pagi dengan konsentrasi belajar anak Sekolah Dasar Negeri 2 Balerejo Kabupaten Madiun.

\section{Bagi Orang Tua}

Diharapkan kepada orang tua siswa dapat di jadikan tambahan pengetahuan tentang pentingnya membiasakan sarapan pagi pada anak sebelum mengikuti proses belajar mengajar di sekolah, agar anak terbiasa sarapan pagi setiap hari dan mampu meningkatkan konsentrasi belajar pada anak.

\section{Bagi Peneliti Selanjutnya}

Penelitian ini hanya menganalisis adanya hubungan sarapan pagi dengan konsentrasi belajar anak Sekolah Dasar Negeri 2 Balerejo Kabupaten Madiun, dapat dilakukan intervensi untuk keluarga agar dapat memberi dukungan anak agar rajin sarapan sebelum berangkat sekolah, dapat melakukan penelitian lebih lanjut tentang faktor-faktor yang dapat mempengaruhi konsentrasi belajar pada siswa selain faktor kebiasaan sarapan pagi yang terbukti berhubungan signifikan terhadap tingkat konsentrasi belajar pada siswa sekolah dasar.

\section{Bagi Responden}

Penelitian ini diharapkan dapat mendorong untuk selalu menjaga asupan gizi melalui sarapan supaya meningkatkan daya konsentrasi belajar. 


\section{DAFTAR PUSTAKA}

Alamin. 2014. Perubahan konsumsi pangan dan pola makan anak. Yrama widya. Bandung

Annas. 2011. Hubungan kesegaran jasmani, hemoglobin (Hb), status gizi dan makan pagi terhadap prestasi belajar. Jurnal ilmu keolahragaan Indonesia. Vol. 1. Edisi 2.FKIP Universitas Respati Yogyakarta

Anam. 2012. Hubungan Kebiasaan Sarapan Pagi Dengan Tingkat Konsentrasi Belajar Pada Anak. No 5.

Arikunto. 2010. Prosedur Penelitian: Suatu Pendekatan Praktek. Jakarta: Rineka Cipta.

Arifin amhar maulana.2014. belajar dan faktor yang mempengaruhinya. Rineka cipta. Jakarta

Azwar. 2012. Peranan gizi dalam siklus kehidupan. Kencana prenada medya group. Jakarta.

Departemen Kesehatan RI; 2010. Departemen Kesehatan RI. Riset Kesehatan Dasar (Riskesdas). Jakarta.

Dinas Kesehatan Jawa Timur; 2018. Departemen Kesehatan RI. Riset Kesehatan Dasar Jawa Timur.

Gomo. 2010. Makanan untuk tubuh. Erlangga. Jakarta

Hakim. 2013. Mengatasi gangguan konsentrasi dan teknik latihan konsentrssi. Puspa suara. Jakarta.

Hardinsyah, \& Aries. 2012. Jenis pangan sarapan dan perannya dalam asupan gizi harian anak usia 6-12 tahun di Indonesia. Jurnal Gizi dan Pangan, 7(2), 89-96.

Hidayat. 2007. Metode Penelitian Keperawatan dan Teknik Analisa Data. Salemba Medika. Jakarta

Irdiana. 2017. Hubungan kebiasaan sarapan dan asupan zat gizi dengan status gizi siswi SMAN 3 surabaya. Diakses tg108 juni 2019.

Irmawati.Hubungan gangguan pendengaran dengan prestasi belajar siswa. Diponogoro University Repository. 2010. hlm 9.

Izzati. 2008. Psikologi belajar. Raja gravindo persada. Jakarta.

Jamarah, syaful bahri. 2008. Pendekatan dalam proses belajar mengajar. Remaja karya. Bandung

Khomsan. 2014. Sarapan dan faktor yang mempengaruhinya. Rineka Cipta. Jakarta

Moehji S. 2013. Ilmu gizi 2. Penerbit papas sinar sinarti salemba medika: jakarta.

Mudjiono. 2010. Psikologi perkembangan anak. Gunung mulya. Jakarta

Munir. 2010. Pendidikan Karakter Membangun Karakter Anak Sejak dari Rumah. Yogyakarta: PT Pustaka Insan Madani.

Nasution. 2002. Belajar dan Pembelajaran. Jakarta: Sangung Seto.

Nazir. 2011. Metode Penelitian. Ghalia Indonesia. Bogor

Notoatmodjo. 2012. Metodologi Penelitian Kesehatan. Rineka Cipta. Jakatra

Notoatmodjo. 2010. Promosi Kesehatan Teori dan Aplikasi. Jakarta : Rinerika Cipta.

Nursalam. 2008. Konsep dan Penerapan Metodelogi Penelitian Ilmu Keperawatan. Jakarta: Salemba Medika.

.2016. Metodologi Penelitian Ilmu Keperawatan. Salemba Medika. Jakarta

Parreta. 2009. Makanan untuk otak. Erlangga. Jakarta.

Purwanto. 2010. Belajar mengatasi hambatan belajar. Prestasi pustaka. Surabaya

Rosa. 2014. Berbagai cara pendidikan gizi. Bumi aksara. Jakarta.

Ristiyati. 2014. Hubungan antra status gizi dan prestasi belajar murid SD negeri di kecamatan tuntang kabupaten semarang. Fakultas kedokteran. Universitas muhammadiyah Surakarta.

Ruwaidah. 2008. Pengaruh Strategi Genius Learning Terhadap Hasil Belajar Siswa Kelas VII Semester 2 Mts Azizi Medan Pada Pokok Bunyi Tahun Ajaran 2007/2008. UNIMED.

Saragi. 2015. Hubungan sarapan pagi dengan aspek biologis anak usia sekolah. Program studi ilmu keperawatan. Universitas Riau. Vol 2 No 2.

Sardiman. 2007. Proses belajar mengajar. Jakarta: Bumi Aksara

Saroso. 2019. Promosi kesehatan dan perilaku kesehatan anak remaja. Rineka cipta. Jakarta

Sartika. 2012. Kebiasaan sarapan pada anak remaja. Skripsi bogor: jurusan gizi masyarakat, fakultas pertanian intitut pertanian bogor.

Setiani. 2014. Mendampingi anak belajar, bebaskan anak dari stres dan depresi belajar. PT elex media computindo. Jakarta 
Setyo purwanto. 2010. Hubungan konsentrasi belajar dan penyesuaian diri pada siswa kelas VII di SMPN 1 ciawigebang tahun ajaran 2009/2010. Fakultas ilmu pendidikan. Universitas negeri yogyakarta.

Slameto. 2010. Belajar dan faktor-faktor yang mempengaruhinya. Jakarta: Rineka Cipta.

Slameto . 2002. Belajar dan Pembelajaran. Jakarta: Rineka Cipta.

Sudjana. 2009. Penilaian Hasil Proses Belajar Mengajar. Bandung: PT Remaja Rosdakarya.

Sudrajat. 2008. Pengertian Pendekatan, Strategi, Metode, Teknik dan Model Pembelajaran. Bandung: Sinar Baru Algensindo.

Sunarti. 2006. Sarapan dan jajan berhubungan dengan konsentrasi pada remaja. Jurnal gizi klinik indonesia. Diakses pada 20 juni 2019

Suralaga. 2018. Interaksi \& Konsentrasi Belajar Mengajar. Jakarta: Rajawali Press.

Suwardhani. 2013. Konsentrasi belajar dan penyesuaian diri pada siswa kelas VII di SMPN 1 garut tahun ajaran 2012/2013. Fakultas ilmu pendidikan. Universitas negeri Yogyakarta.

Syahnur. 2012. Kebiasaan Sarapan Pagi. Bandung: Sinar Baru Algensindo.

Tamsuri. 2010. Hubungan kebiasaan sarapan pagi dengan tingkat konsentrasi belajar pada anak. Puskesmas kasembon.

Yudi. 2008. Sarapan dan jajan berhubungan dengan konsentrasi belajar pada remaja. Jurnal gizi klinik indonesia

Yusuf samsul. 2013. Psikologi perkembangan anak dan remaja. PT BPK gunung mulia. Jakarta 